\title{
Evaluation of bivalent inactivated oil adjuvant African Horse Sickness vaccine in Guinea pigs and mice
}

\author{
Nashwa K. Madkour, S. K. Rofaiil. \\ Veterinary Serum and Vaccine Research Institute, Abbasia, Cairo, Egypt.
}

\begin{abstract}
In this study, neutralizing antibody response in Guinea pigs and mice inoculated by African horse sickness (AHS) bivalent inactivated oil adjuvant vaccine was similar when compared serologically with that in horse. Therefore, using G. pigs and mice may be a method of great value in potency test for routine immunization. Potency test of the prepared vaccine using an immunization challenge protocol in adult mice was studied, using challenge virus with 100,50 and $25 \mathrm{LD}_{50}$. The highest protection level $(95 \%)$ was with the dilution of $50 \mathrm{LD}_{50} / 0.05 \mathrm{ml}$.
\end{abstract}

African horse sickness (AHS) is an acute and/or subacute infectious non-contagious, seasonal, arthropod-born viral disease of Equidae.

The disease has 4 forms; a peracute or pulmonary form, subacute or cardiac form, an acute mixed form and a horse sickness fever (Erasmus, 1973).

The disease is transmitted by two groups of biological vectors, culicoides and mosquitoes (Dutoit, 1944; Ozawa et al., 1966).

The aetiological agent of AHS is one of the members of family Reoviridae, genus Orbivirus which comprises nine serotypes of AHSV, 7 serotypes stated by McIntosh (1958) and serotypes 8 and 9 were identified by Howell (1962).

In 1994, the General Organization of Veterinary Services (GOVS) in Egypt decided to stop AHS vaccination program according to American Project No. 169 PL 480 (1977) and instructed the Veterinary Serum and Vaccine Research Institute, Abbasia, Cairo (VSVRI) to stock-pile the vaccine for emergency.

The last wave of epizootics was recorded in South of Sapin, Portugal, Morocco, Kenya and Southern region of Iberian Peninsula between 1987 and 1990. The causative agent was AHSV serotype 4 (OIE, Report, 2004). In 1989, AHS serotype 9 was reported in Saudi Arabia (Anderson et al., 1989; Mellor et al., 1990).

Since both serotypes 4 and 9 were the predominant types of AHSV causing the last wave of epizootics. Thus such serotypes were used in the preparation of bivalent inactivated AHS oil adjuvanted vaccine.
As the implementation of any research program was hampered by the lack of large numbers of a readily available, inexpensive animal of uniform susceptibility or particular susceptibility for a specific purpose, the present work was planned to investigate the possibility of finding alternative experimental laboratory animal to replace or supplement the horses in evaluating the potency of inactivated AHS vaccine (OIE, Report, 2004).

\section{Material and methods}

Horses. Three apparently healthy and susceptible adult horses 2-4 years old were (in horse stables of Veterinary Serum and Vaccine Research Institute, Abbasia, Cairo) used for testing the potency of AHS tissue culture (TC) inactivated oil adjuvanted vaccine and one horse was kept as a control. Their pre-vaccination sera were serologically tested by SNT, CFT and ELISA to ensure the absence of specific antibodies against AHS virus.

Mice.

Suckling Swiss Albino mice. Two litters (8 mice/litter) 3-6 days old suckling mice were used to detect the residual infective virus in the inactivated viral fluid.

Adult mice. Forty mice of 21 days old were used for virus titration and potency testing of the vaccine.

Guinea pigs. Twenty five healthy adult Guinea pigs of approximately 300-400 grams weight were used for potency test of the vaccine.

Virus. Two mouse adapted neurotropic (attenuated) reference strains of AHS virus, serotype 9 (S2) (Mo 103) which was obtained from Plum Island, Department of Agricultural Research Service, USA and serotype 4 (vryhied) 
which was obtained from Onderstepoort Laboratory, South Africa. They were subjected to 4-5 successive passages on monkey kidney stable cell (MS) cell cultures (Ms 4-5) which were obtained from Plum Island, USA and passaged for 3-4 passages on Vero cell cultures (Vero 3-4) at Veterinary Serum and Vaccine Research Institute, Abbasia, Cairo (VSVRI). These strains were stored in the form of freeze dried preparations.

Antisera. Goat hyperimmune sera against AHS virus serotypes 4 and 9 received from Department of Agricultural Research Service, Plum Island, USA, as reference serum were used in identity test of the selected vaccine seed virus of serotypes 4 and 9 .

Identity test. The selected vaccine seed virus of serotypes 4 and 9 was confirmed by virus neutralization test (VNT) with reference homologous goat antisera (OIE, 2004).

Virus Neutralization Test (VNT). It was performed according to Hazarati and Ozawa (1968) TCID $_{50}$ tissue culture infective dose fifty, as calculated by the method of Reed and Muench (1938).

Preparation of AHS tissue culture inactivated oil adjuvanted vaccine. AHS master seed virus serotypes 4 and 9 were propagated intracerebrally in mice for 3 successive passages and another 3 passages on Vero cells.

AHS working seed virus serotypes 4 and 9 were inoculated separately on Vero cells, incubated at $37^{\circ} \mathrm{C}$ for 2-3 days until maximum cytopathic effect (CPE) was developed. The virus fluids were harvested, tested for sterility and titrated on Vero cell culture. The infectivity titer of the virus fluids were estimated as $\log _{10} \mathrm{TCID}_{50} / \mathrm{ml}$. An equal volumes of virus fluids of serotypes 4 and 9 were mixed with titer 8.5 and $9.5 \log _{10}$ $\mathrm{TCID}_{50} / \mathrm{ml}$; respectively, then inactivated with Binary ethyleneimine (BEI) at a final concentration $0.004 \mathrm{M}$ with continuous stirring at $37^{\circ} \mathrm{C}$ for 24 hours followed by immediate addition of sterile sodium thiosulphate at a final concentration $2 \%$ to stop the action of BEI on the virus and neutralize the toxic action of residual inactivator on target host (Hassanain, 1992).

Inactivated virus fluid was examined for residual infective virus on both suckling mice and Vero cell culture (Stellmann et al., 1969; Mirchamsy et al., 1973). Inactivated virus fluid together with $5 \%$ Tween 80 (aqueous phase) was mixed with oil adjuvant (90\% Marcol, 10\% Span 80) (oil phase) in a ratio of $1: 2$ with the addition of 0.001 merthiolate as preservative (Thomas, 1993).

Calculation of challenging doses. The titer of challenged virus of types 4 and $9\left(6.5-7.0 \log _{10}\right.$ $\mathrm{LD}_{50} / 0.05 \mathrm{ml}$, respectively) was determined by $\mathrm{I} / \mathrm{C}$ inoculation of groups of mice with serial ten fold dilutions of AHSV serotypes 4 and 9 and calculated by the method of Reed and Muench (1938) expressed as lethal dose $50\left(\mathrm{LD}_{50}\right)$. Each virus was diluted to contain 25,50 and 100 $\mathrm{LD}_{50} / 0.05 \mathrm{ml}$ as described by Habel (1973).

\section{Vaccination schedule.}

Horses. Three susceptible horses were inoculated deep $\mathrm{I} / \mathrm{M}$ with two doses of the prepared AHS TC inactivated oil adjuvanted vaccine $(5 \mathrm{ml} /$ horse $)$ at 4 weeks interval. One horse was kept as a control. Serum samples were collected two weeks after booster dose and subjected to virus neutralization test (VNT) (OIE, 2004).

Guinea pigs. Twenty Guinea pigs were inoculated with the prepared AHS TC inactivated oil adjuvanted vaccine. Each one received the recommended horse dose (5 $\mathrm{ml} /$ Guinea pigs) by subcutaneous (S/C) injection. Five Guinea pigs were kept as control. Serum samples were collected at 21 days post inoculation and subjected to VNT (OIE, 2004).

Mice.Twenty mice received 2 doses of AHS TC inactivated oil adjuvanted vaccine with one week interval, each one received $0.5 \mathrm{ml}$ by $\mathrm{S} / \mathrm{C}$ route, 10 mice were kept as non-inoculated control group under the same conditions of the experiment. Serum samples were collected at 21 days from the $1^{\text {st }}$ inoculation and subjected to VNT. At the same time, challenging of both vaccinated and control group of mice was performed using AHSV (types 4 and 9) prepared from infected mice brain emulsion at a dose of $0.05 \mathrm{ml} / \mathrm{mice}$ of each serotype by intracerebral route (I/C) (Moussa et al., 1966, Hassanain, 1983).

\section{Results and Discussion}

Some countries specially those free from AHS do not permit the introduction of attenuated polyvalent AHS vaccines, since horses vaccinated with this attenuated vaccine have a risk of spreading the virus or the presence of specific antibodies hinders the participation of these vaccinated horses in races outside the original country.

So, OIE Report (2004) has been suggested the need of these countries for the use of an efficient inactivated vaccine of AHS virus. 
Table (1): Infectivity titer of AHS virus serotypes 4 and 9 in mice

\begin{tabular}{ccc}
\hline No. & Infectivity titer expressed in $\log 10 \mathbf{L D}_{\mathbf{5 0}} / \mathbf{m l}$ \\
\cline { 2 - 3 } Passages & Serotype 4 & Serotype 9 \\
\hline 1 & 5.0 & 5.5 \\
2 & 5.5 & 5.7 \\
3 & 5.8 & 6.0 \\
\hline
\end{tabular}

Table (2): Infectivity titration of AHS virus serotypes 4 and 9 in Vero cells

\begin{tabular}{ccccc}
\hline $\begin{array}{c}\text { Passages } \\
\text { No. }\end{array}$ & \multicolumn{2}{c}{$\begin{array}{c}\text { Time of harvestation in days post } \\
\text { inoculation }\end{array}$} & \multicolumn{2}{c}{$\begin{array}{c}\text { Infectivity titer } \\
\left(\log _{\mathbf{1 0}} \mathbf{T C I D}_{\mathbf{5 0}} \mathbf{\text { ml }}\right)\end{array}$} \\
\cline { 2 - 5 } & Serotype 4 & Serotype 9 & Serotype 4 & Serotype 9 \\
\hline 1 & 4 & 3 & 6.5 & 7.0 \\
2 & 3 & 2 & 7.5 & 8.2 \\
3 & 2 & 2 & 8.5 & 9.5 \\
\hline
\end{tabular}

Table (3): The immune response of AHS bivalent inactivated oil adjuvanted vaccine in lab animals and horses

\begin{tabular}{ccc}
\hline \multirow{2}{*}{ Animal } & \multicolumn{2}{c}{ Neutralizing index against AHSV } \\
\cline { 2 - 3 } & Serotype 4 & Serotype 9 \\
\hline Guinea pigs & $3.5^{*}$ & $4 *$ \\
Mice & $3 *$ & $3.5 *$ \\
Horse 1 & 3.50 & 4.00 \\
Horse 2 & 4.00 & 4.50 \\
Horse 3 & 3.75 & 4.25 \\
& $3.75^{*}$ & $4.25^{*}$ \\
\hline
\end{tabular}

* Mean neutralizing index

- Control animals showed -ve results

Table (4): Potency test of AHS bivalent inactivated oil adjuvant vaccine in mice

\begin{tabular}{ccc}
\hline LD50 of challenge & \multicolumn{2}{c}{ Percentage of death in challenged mice } \\
\cline { 2 - 3 } virus & Vaccinated group & Control group \\
\hline$* 100$ LD50 & 25 & 100 \\
$* 50$ LD50 & 5 & 100 \\
$* 25$ LD50 & 0 & 80 \\
\hline
\end{tabular}

* Dilutions of challenge virus.

The efficacy of inactivated vaccine is estimated either by measuring the quantity of antigenic material in the vaccine or by performing potency test in target animals as horses or small laboratory animals such as mice or Guinea pigs. Potency test may be direct by employing a vaccination - challenge protocol or indirect by measuring the antibody level (Frerichs and Coral, 1973).

A potency test was based on the determination of neutralizing antibody level following vaccination would be a satisfactory method of assessing the efficacy of a given vaccinal batch but it is impractical to carry out such test routinely in horses. As an alternative to use horses, the antibody response of laboratory animals may prove to be a suitable means of assessing the vaccine efficacy (Frerichs and Coral, 1973). Thus, the present study aimed to evaluate the immunogenic response of laboratory animals inoculated with AHS bivalent inactivated oil adjuvanted vaccine and compared that with the immunogenic response of horses.

Using of $G$. pigs in determining the immunogenicity of the prepared vaccine by indirect potency test have been recommended by Erasmus, 1963; Stellman et al., 1969; Doubourget et al., 1992; OIE, 2004).

The results in Table (1) indicated that the infectivity titer of AHS virus serotypes 4 and 9 which were propagated for three successive passages intracerebrally in mice were 5.8 and 6 
$\log _{10} \mathrm{LD}_{50} / \mathrm{ml}$, respectively. Table (2) showed that the infectivity titer of the AHSV. Serotypes 4 and 9 propagated for another 3 passages on Vero cells were 8.5 and $9.5 \log _{10} \mathrm{TCID}_{50} / \mathrm{ml}$, respectively, which used a vaccine preparation. The titers used for vaccine preparation were in accordance with the recommendation of Mirchamsy and Taslini (1967) who concluded that the infectivity titer of each serotypes should not less than $6.5 \log _{10} \mathrm{TCID}_{50} / \mathrm{ml}$ in order to be acceptable for inactivated vaccine preparation. The results in Table (3) showed that the mean value of neutralizing indices in sera of G. pigs, mice and horses which immunized with bivalent inactivated oil adjuvant AHS vaccine were 3.5, 4.0 in G. pigs, 3.0, 3.5 in mice and 3.75, 4.25 in horses for types 4 and 9 respectively. These results agreed with Bourdin et al., (1970) who showed that horses immunized with T9 strain S2 inactivated vaccine developed neutralizing antibody resistant to challenge with virulent virus at 45 days post vaccination with $(\mathrm{NI}=4)$, at 9 months post vaccination with $(\mathrm{NI}=4)$ and at 15 months post vaccination with $(\mathrm{NI}=2.2)$. Also, OIE (2004) recorded that horse should develop a neutralizing antibody titer of at least $20\left(1.3 \log _{10}\right)$ against at least three of the four serotypes in the quadrivalent vaccine. From the previous results, it was appeared that there is a clearly defined correlation between the serological (neutralizing antibody) response in G. pigs, mice and that of horses. Suggestion the use of G. pigs and mice may be a method of great value as indirect potency test for routine immunization because of its economic-flexible and of less risk than direct challenge.

Naturally, the ideal method for direct potency test is the use of horses but it was impossible to get number of horses sufficient for such experiment and using of virulent strains for challenge was forbidden, for these reasons, mice were selected to determine the potency of AHS bivalent inactivated oil adjuvanted vaccine using an immunization challenge protocol (Habel, 1973) as they challenged later by the same mouse adapted virulent strain of type 4 and 9 which diluted to contain 25, 50 and 100 $\mathrm{LD}_{50} / 0.05 \mathrm{ml}$. It was found that $100 \mathrm{LD}_{50}$ can kill $25 \%$ of vaccinated mice, $50 \mathrm{LD}_{50}$ was able to kill $5 \%$ of vaccinated mice, while both of them lead to $100 \%$ deaths in control mice, while by using $25 \mathrm{LD}_{50}$ as challenging dose no deaths in vaccinated mice but it lead to $80 \%$ deaths of control mice (Table 4). From above mentioned results, it appeared that we propose the use of the challenge virus in a dilution between 50 to 100 $\mathrm{LD}_{50} / 0.05 \mathrm{ml}$, preferably $50 \mathrm{LD}_{50}$. In conclusion, the study propose an alternative system for evaluation of the AHS inactivated vaccine using mice or G. pigs in the potency test to replace horses.

\section{Acknowledgement}

The authors would like to thank Prof. Dr. Ibrahim Soliman, Head of Equine Viral Disease Vaccine Research Dept., VSVRI for his advice ad guidance to accomplish this work.

\section{References}

Anderson, E.G.; Mellor, P. and Hamblin, C. (1989): AHS in Saudi Arabia. Vet. Rec., 125 (19): 482-489.

Bourdin, P.; Monnier-Combon, J.; Rioche, M. and Laurent, A. (1970): Evaluation of an inactivated vaccine. Proc. $2^{\text {nd }}$ Int. Conf. Equine Infectious Disease, Paris, 1969, pp. 202-206.

Dubourget, P.; Preand, J.M.; Detraz, N.; Lacoste, F.; Fabry, A.C.; Erasmus, B.J. and Lombard, M. (1992): Development, production and quality control of an industrial inactivated vaccine against African horse sickness virus serotype 4 . In blue tongue, African horse sickness and related orbiviruses. Proc. 2nd Int. Symp. (Edited by Walton, T.E.; Osburn, B.I.). Boca, Raton, USA, 874-886.

Dutoit, P.J. (1944): The transmission of blue tongue and horse sickness by Culicoides. Onderstepoort, J. Vet. Sci., 19: 7-16.

Erasmus, J.B. (1963): Preliminary observations on the value of the Guinea pig in determining the innocuity and antigenicity of neurotropic attenuated AHS strains. Onderstepoort J. Vet. Res., 36 (1): 11-22.

Frerichs, G.N. and Coral, C.F. (1973): Serological response of chickens, rabbits and Guinea pigs to Equine Influenza vaccines. Res. Vet. Sci., 14: 187-193.

Habel, K. (1973): Habel test for potency of rabies vaccine in laboratory techniques in rabies, Ed. by Martin M. Kaplan and Hilary Koprowski. WHO, Geneva, Chapter 31; pp. 279-280.

Hassanain, M.M. (1983): Further studies on diagnosis and control of African horse sickness disease. Ph.D., Microbiology, Fac. Vet. Med., Cairo Univ.

Hassanain, M.M. (1992): Preliminary findings for an inactivated African horse sickness vaccine using binary ethyleneimine. Rev. Elev. Med. Vet. Pays Trop., 45 (3-4): 231-234.

Hazarati, A. and Ozawa, Y. (1968): Quantitative studies on the neutralization reaction between AHSV and antisera. Arch. Ges. Virusforsch, 25: 83-92.

Howell, P.G. (1962): The isolation and identification of further antigenic types of AHS virus. Onderstepoort J. Vet. Res., 29 (2): 139-149.

McIntosh, B.M. (1958): Immunological types of AHS virus and their significance in immunization. Onderstepoort J. Vet. Res., 27: 465-538.

Mellor, P.S.; Hamblin, C. and Graham, S.D. (1990): African horse sickness in Saudi Arabia. Vet. Rec., 127 (2): 41-42.

Mirchamsy, H. and Taslimi, H. (1967): Serological response of horses immunized with live attenuated African horse sickness vaccine. J. Comp. Pathol., 77:431-438.

Mirchamsy, H.; Hazarati, A.; Bahrami, S.; Shafyi, A. and Nazari, P. (1973): Development of new African horse sickness cell culture killed vaccines. Proc. $3^{\text {rd }}$ Int. Conf. Equine Infectious Diseases, Paris (1972), 81-87. 
Moussa M. Tadros; Zeinab, M.A. Saad and Bahiga M. Youssef (1966): The serum-virus neutralization test by intracerebral inoculation route in white mice as a method for diagnosis and typing of horse sickness viruses. J. Arab Vet. Med. Assoc., XXVI (1-2): 33-66.

OIE (2004): African horse sickness, OIE Meeting Report, Chapter 2.1.11.

Ozawa, Y.; Nokata, G.; Shod-del, F. and Navai, S. (1966): Transmission of AHS by a species of mosquito, Aedes aegyptilinnaens. Amer. J. Vet. Res., 27 (118): 695697.

Parker, J. (1974): AHSV antibodies in Cyprus 1971-72.
Vet. Rec., 94: 370-373.

Reed, L.J. and Muench, H. (1938): A simple method of estimating fifty percent end point. Amer. J. Hyg., 27: 493497.

Stellmann, C.; Santucci, J.; Gilbert, H. and Favre, H. (1969): A method for control in production of inactivated AHS vaccine. Proc. $2^{\text {nd }}$ Int. Conf. Equine Infectious Diseases, Paris, 207-211.

Thomas, O. (1993): Vaccine adjuvants and carriers. Vaccine for veterinary applications. Cited by Peters; A.R., Chapter 11, 295-306.

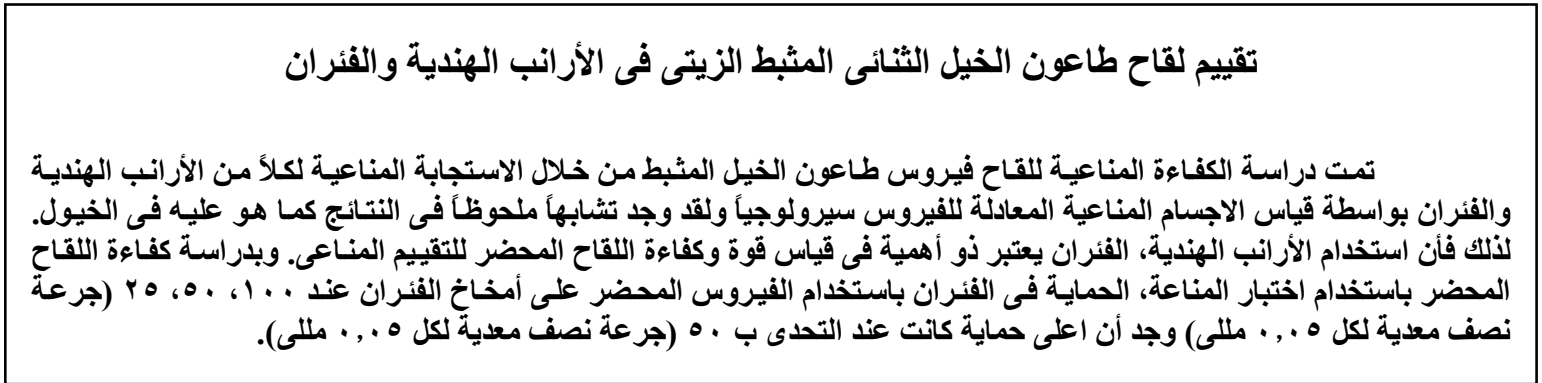


